\title{
The European Security Architecture and Turkey
}

\author{
Ergun Mengi*
}

\begin{abstract}
Europe has been surrendered by instable regions. Improving its defense capabilities and crisis management functions within the ESDP, the EU's chances will enhance on the world scene.

In this article, the current capacity of the European security architecture and Turkey's position is analyzed. EU countries claim that NATO must remain for collective defense, but responsibility for crisis management and peace support operations must be shouldered by the EU. In this case, NATO may turn into a marginal organization, like the WEU in 1954, if it does not update its missions and responsibilities.

The article explores the development of the European security architecture and Turkey's position within it. Turkey has sought to find ways to cooperate on NATO-EU cooperation under ESDP; however the EU did not fulfill its promises which led to the withdrawal of Turkey's military support to the EU in 2007. In addition, Turkey strongly objected Greek Cypriot government's co-operation with NATO and its participation in the EU's ESDP which was blocked by the NATO-EU Security Agreement.
\end{abstract}

\section{Keywords}

ESDI, ESDP, European Security, WEU, Petersberg Tasks.

* Rear Admiral (Ret.) Ergun Mengi is a PhD candidate in the Department of International Relations, Ankara University, Ankara, Turkey. 


\section{Introduction}

The European Security Architecture, starting with the establishment of the Western European Union (WEU) in 1948 before NATO's establishment, has had its ups and downs, only to gain momentum again with the revitalization of the WEU in 1991 and the development of the European Security and Defense Identity (ESDI). With the WEU transferring its functions to the European Union (EU), developments have continued within the EU framework.

What was the specific necessity for the EU to develop an institutional historical framework other than NATO? Parallel to other developments, it was necessary for the EU to combine its economic and political capacity with its defense and military power in order to become a super power having a role within world politics and to protect/supervise the worldwide interests of EU member states. It has achieved this to a certain degree.

The European Security Architecture starting with ESDI has continued with the development of the ESDI within NATO and eventually has become the European Security and Defense Policy (ESDP) in the EU.

Despite some shortcomings when compared with US military power and NATO, the ESDP has made progress so far. Following the end of the bipolar world, European security concerns have gained a more global dimension. NATO's principle tasks of collective defense against the Soviet threat have lost their importance, and regarding the new global concerns NATO has initiated efforts to renew itself. Observing the crises and interventions in the world, the EU will attempt, by developing its defense dimension, to become an institution that is more effective than NATO in the issue of crisis management. However, it is possible that the ESDP, if it alienates Turkey, will be inefficient in intervening in crises which fall within the scope of the EU's security concerns. Europe experienced two world wars and has 
overcome the Cold War without damage. Its security is important for global peace. Looking at the global crises taking place in this period where a bipolar world was dissolved and the EU is struggling to complete its integration process, this article aims to shed light on what the EU's direction of defense efforts will be in the future and what are the Europe's post-cold war security concerns?

This article will examine the structuring of the EU's Common Foreign and Security Policy (CFSP), in light of the historical period including the developments within the institutions of the WEU, NATO and the EU.

\section{I) European Security Policies after World War II}

In order to understand the current structure of the ESDP, a brief examination of its background is necessary. Based on the idea of establishing an alliance within the understanding of "all for one, one for all" against Germany and Italy, which were regarded as threats to Europe emerging from World War II, the WEU was founded with the 1948 Treaty of Brussels ${ }^{1}$ with the participation of France, the UK, the Netherlands, Belgium and Luxembourg. However, later on, with the initiatives of the USA and the UK, the Treaty of Washington was signed in 1949 and NATO was established. As the first Secretary General Lord Ismay has stated, "NATO was designed to keep Americans in, the Russians out and the Germans down for the security of Europe". Turkey has become a part of the European security architecture by becoming a member of NATO in 1952.

\footnotetext{
1 "Origins of WEU: from the Brussels Treaty to the Paris Agreements (19481954)", < bttp:/ / wmw.weu.int>, (access date: 10 March 2010).

2 David Reynolds, The Origins of the Cold War in Europe: International Perspectives, London, Yale University Press, 1994, p. 13.
} 
In 1954, parallel to NATO's strategy, the WEU revised the Treaty of Brussels with the Paris Protocol and included Germany and Italy in the WEU for the potential Soviet threat against Europe. However, since European security was generally taken on by NATO and the US, the WEU so to speak, entered into hibernation from 1954 onwards.

In 1944, the basic idea behind the French Foreign Policy was that "German presence is the essential problem of the world. There is no need to be afraid of Russians. We need to know how to work together with Russia against our common enemy Hitler", ${ }^{3}$ and put forth the idea of creating a European Army under the name "PLEVEN Plan" and has started the works of a European Defense Community (EDC) in 1950 to prevent Germany's NATO initiative. French Prime Minister Rene Pleven believed that the creation of the European Army was a first step towards a united Europe. ${ }^{4}$ As can be understood from this statement, the goal from the start has been to form a united Europe. A united Europe not being possible without a defense dimension will later on be mentioned and will be discussed below. However, this initiative for EDC was surprisingly rejected by the French Parliament on 30 August 1954. This action paved the way for Germany to join NATO (30 December 1954). Relations between France and Germany, which were highly tense up to that time, started to improve with the 1955 Treaty of Paris and developed further with the Treaty of Rome.

Later on, France, under De Gaulle, wanted Europe to become one of the major players again. De Gaulle believed that the actions of non-European great powers dominating the world did not show the necessary harmony with Europe's supremacy and

\footnotetext{
3 Alfred Grosser, "France and Germany in the Atlantic Community", International Organization, Vol. 17, No. 3 (1963), p. 551.

${ }^{4}$ See: The Text of the Pleven Plan. "The army of a united Europe, composed of men coming from different European countries, must, so far as is possible, achieve a complete fusion of the human and material elements which make it up under a single European political and military authority...”, 24 October 1950.
} 
power. De Gaulle didn't accept that non-Europeans were deciding about Europe's destiny, upon the causes and results of World War II. And thus, he directed his policies under this principle. ${ }^{5}$

European Political Cooperation, constituted by a Joint Foreign Policy and Defense and Security policies organized by France, was blocked by the Benelux countries. Thus a "Common Foreign Policy" could not be formed during the European integration process throughout the Cold War period. France preferred a European security architecture which would be completely independent from NATO and the USA. Therefore, France has persistently opposed the US dominance within NATO. France's unease regarding this issue was voiced by Jean-Marie Le Pen as "relations within the alliance of NATO must be in accordance with the principle of equality. Otherwise, NATO will become an instrument of the US dominating Europe and the Western world. If this is the case, we must leave this institution together and abandon NATO". "Despite the approval of the defense strategy and joint nuclear power initiative developed by US Defense Minister McNamara at the Bahamas by US President Kennedy, the UK Prime Minister Macmillian, and Federal Germany, De Gaulle's France has opposed this initiative and taken the decision to form its national nuclear power. De Gaulle, putting forward that NATO is an establishment under the control of the US and that the European Security system must be autonomous, has taken France out of NATO military command with a decision taken on March 1966.

\section{European Security and Defense Initiatives after 1980}

The early 1980s witnessed a revival of the debate on European security. Changes in defense understandings in the beginning of the 1980s, the US's leading role in the defense

\footnotetext{
5 Stanley Hoffman, "De Gaulle, Europe, and the Atlantic Alliance", International Organization, Vol. 18, No. 1 (1964).

6 Alfred Grosser, "France and Germany...", p. 560.
} 
industry, Europe's effort to create a harmonized defense industry, and the rivalry of building strategic defense missile between the US and the Soviet Union has led to the creation of new ideas in European states regarding security issues. The first outcome of these ideas was seen in 1984, on the 30th anniversary of the Treaty of Paris, in the meeting of WEU Foreign and Defense Ministers in Rome. In this meeting, the decision to begin working towards the WEU becoming active again, defining European Security and Defense Identity, and harmonization of the defense policies of member states were guaranteed.7 In accordance with the decisions taken in Rome, the WEU Council of Ministers came together at The Hague on 27 October 1987, and has conveyed a very important message by stating that "We are convinced that the construction of an integrated Europe will remain incomplete as long as it does not include security and defense".

Towards the end of the 1980s, significant changes were observed in Europe. European states were not only making decisions on an independent defense policy separate from the US, but more importantly, on the harmonization of defense policies.

The WEU Council of Ministers meeting concurrently with the EU Maastricht Treaty accepted the ESDI with the Maastricht Declaration. In the Declaration, it was foreseen that the WEU should act as the European pillar of the Alliance and the defense component of the EU. The WEU was a highly complex establishment. It had 10 full member countries, consisting of the UK, Germany, France, the Netherlands, Belgium, Luxembourg, Spain, Portugal, Italy and Greece, which were members of both NATO and the EU, associate member countries of Turkey, Norway and Iceland which were members of NATO but not the EU, and observer status countries of Ireland, and after 1995, Sweden, Finland, Austria which were members of the EU, but not

7 WEU Rome Declaration, 26-27 October 1984, para. 2, 4.

8 See: The Hague Platform (27 October 1987), Platform on European Security Interests, <http://www.weu.int/documents/871027en.pdf>, (access date: 13 April 2010). 
The European Security Architecture and Turkey

NATO. Denmark had the right of full membership but chose to take on an observer status. With the gains obtained at the beginning and others built on, Associate Members such as Turkey ${ }^{9}$ have almost reached a position in which they have come closer to the rights of full member states. In Treaty of Brussels, the task of the WEU was to ensure the collective defense of its member countries (just like the article five in NATO). However, following the end of the Cold War, collective defense was replaced with the tasks of peace-keeping, peace-making and peace for partnership (PfP) operations. The WEU has defined its functions accordingly and has declared them with the Petersberg Declaration of 19 June $1992 .^{10}$

\section{Development of the ESDI within the Alliance}

Once the Cold War came to an end, European public opinion did not appreciate additional defense expenses for the ESDI. Therefore, what had to be done was to transfer NATO's assets and capabilities to the WEU. However, the USA declared that the burden-sharing is necessary within NATO. A European defense structure would mean a reduction in monetary and manpower costs for the U.S. and of course an increasing of the European Allies' defense budgets. Since 1990, the negotiation is on the table and the U.S. military presence in Europe has declined by two-thirds from a high of over 300,000 to under 100,000 today. ${ }^{11}$

\footnotetext{
${ }^{9}$ See: Document on Associate Membership of WEU of the Republic of Iceland, the Kingdom of Norway and the Republic of Turkey, Rome, 20 November 1992: "they will take part on the same basis as full members in WEU military operations to which they commit forces".

10 "Petersberg Declaration", 19 June 1991, <bttp:/ / www.weu.int/ documents/920619peten.pdf>, (access date: 30 April 2010).

10 Anderson Stephanie B., "Developing Europe into a 'Third Great Power Bloc': The United States, France and the Failure of the European Defense Community", <http:// aei.pitt.edu/3269>, (access date: 12 February 2010).

${ }^{11}$ Anderson Stephanie B., "Developing Europe into a 'Third Great Power Bloc': The United States, France and the Failure of the European Defense Community", <http:// aei.pitt.edu/3269>, (access date: 12 February 2010).
} 
Some EU countries, namely the UK, the Netherland and Germany stated that the ESDI will strengthen NATO and included "to improve cooperation with NATO" in the EU's security agenda. France's opposition to NATO-WEU cooperation was partially broken by other EU countries. The WEU's role in strengthening the European pillar of the Alliance, WEU-NATO relations, and the development of the ESDI within the Alliance were discussed and decided at the 1996 NATO Berlin Summit. ${ }^{12}$

With the US and Turkey, the UK, Norway and Denmark were pleased with this decision, since it was thought that fragmentation would not take place with the ESDI's development with NATO and its influence would be melted within the sphere of NATO. However, over time, it was seen that this perception was not correct and this project became "the EU's slicing strategy" and an EU instrument for the ESDP. The development of the ESDI within the Alliance has come up with some projects which are as follows: Assured EU access to NATO planning capabilities able to contribute to military planning for EU-led operations; the presumption of availability to the EU of pre-identified NATO capabilities and common assets for use in EU-led operations; identification of a range of European command options for EUled operations, further developing the role of Deputy SACEUR (DSACEUR) in order for him to assume fully and effectively his European responsibilities; the further adaptation of NATO's defense planning system to incorporate more comprehensively the availability of forces for EU-led operations. In summary, rather than doing something for the development of the ESDI within NATO, European Allies only discussed which NATO capacities will be transferred to the WEU.

12 "Final Declaration", NATO Ministerial Meeting in Berlin, <wmw.nato.int/docu/pr/1996/p96-063e.htm>, (access date: 03 June 1996). 
The European Security Architecture and Turkey

\section{Operations Carried Out by the WEU}

The WEU has improved itself and enhanced its visibility with the operations and tasks in which it has participated, including the Joint WEU Initiative in the Gulf, WEU/NATO Operation Sharp Guard, WEU Danube Operation, WEU Demining Assistance Mission to Croatia, Police Contingent Operation in Mostar, Operation MAPE in Albania, and General Security Surveillance of the Kosovo Region. ${ }^{13}$

\section{The Foundation of the EU's Defense Dimension}

Even though the WEU is taking on the leading role in important developments as a defensive component of the EU and maintains its visibility with the operations in which it participates, these are not satisfying for some EU members. The different membership statuses within the WEU and the complex decisionmaking mechanism have begun to disturb some EU states, especially France. And these countries have voiced the need to establish an independent European Security Architecture from NATO. The EU put forth the EU's Common Foreign and Security Policy (CFSP) with the 1997 EU Amsterdam Treaty as the third pillar of the EU.

1998 marked important developments within the dimension of European security. On 3-4 November 1998, EU Ministers of Defense have come together in Vienna for the first time in history. At the same time, the France-UK meetings were held in the city of St. Malo in France on 3-4 November 1998 which led to the security and defense dimension of the EU to gain a new and significant aspect. ${ }^{14}$ The UK has always shared transatlantic views and defended the mutual benefits of the USA and NATO. With

13 "The History of the WEU", <http:// www.weu.int/History.htm>, (access date: 12 March 2010).

14 "Joint Declaration on ESDP", Franco-British Summit, St. Malo, 04 December 1998. 
the St. Malo meeting the UK has changed its direction. The reason for this is that the UK did not want to be excluded out of the ESDP developments.

In the St. Malo Declaration, the following decisions were taken: The rapid and full implementation of the Amsterdam provisions on CFSP; the EU must have the capacity for autonomous action backed up by credible military forces in order to respond to international crises; contributing to the vitality of a modernized Atlantic Alliance which is the foundation of the collective defense of its members. With this declaration, ESDI, which had pulled the UK to their side, had taken its most significant step on the path in becoming an ESDP. The point in this declaration which draws the most attention is "contributing to the vitality of a modernized Atlantic Alliance", ${ }^{15}$ and in this point, I believe, the modernization of NATO, including its decision mechanisms, by taking ESDP into account, was foreseen.

Following these developments, in the meeting of the EU's General Affairs Council (GAC) on December 7, 1998, it was suggested that a new decision-making process must be set up which allows the use of European forces by the EU Allies within NATO. This means that a new European forum with a full decision-making capacity within NATO. This also means that no veto right for the non-EU Allies like Turkey and the USA, as far as European issues are concerned. Here, the aim of the EU members is to limit NATO within collective security, or with the provisions of Article 5, to form a new decision mechanism related to European crisis management within NATO. As far as crisis management is concerned the EU wants to establish its CFSP with the ability to make decisions on its own, and to attain a Security and Defense capacity for crisis management

15 See: Saint Malo Declaration, Art. 2: "We are contributing to the vitality of a modernized Atlantic Alliance which is the foundation of the collective defense of its members. Europeans will operate within the institutional framework of the European Union". 
The European Security Architecture and Turkey

and promoting peace backed up by credible military forces, and to use NATO assets and capabilities, fulfilling this without any additional expenses. ${ }^{16}$

Article 3 of the Cologne Summit Conclusions reads that the "EU wants to develop an effective EU-led crisis management in which NATO members, as well as neutral and non-allied members, of the EU can participate fully and on an equal footing in the EU operations, arrangements will take place that allow non-EU European allies and partners to take part to the fullest possible extent in this endeavor". ${ }^{17}$ Another important decision taken in Cologne is "the inclusion of those functions of the WEU which will be necessary for the EU to fulfill its new responsibilities by the end of the year 2000" as stated in Article 5. ${ }^{18}$ As stated previously, the EU has shown that it is high time to establish a defense architecture in which decisions will be taken autonomously. EU member states would like to have not only an independent and autonomous institution, but also to utilize NATO assets and capabilities without any restraints and to retain control of the decision mechanism.

On the path of expressing a serious attitude in structuring European security, the report of the Helsinki Summit on 10-11 December 1999 regarding the issue of ESDP has for the first time conveyed the integrated picture related to European Security and Defense. In this Summit, apart from the establishment of a Political Security Committee (PSC), Secretary General and High Representative for CFSP, Military Committee (EUMC), and Military Staff (EUMS), ${ }^{19}$ decisions were made towards the

16 Robert E. Hunter, The European Security and Defense: NATO's Companion-or Competitor, California, RAND Publication, 2002, p. 41.

17 "EU Cologne Summit Decisions", Annex-III, p. 34,

<http:// www.consilium.europa.eu/ueDocs/cms_Data/docs/pressData/ en/ec/kolnen.htm> , (access date: 04 March 2010).

18 "EU Cologne Summit Decisions", Annex-III, p. 35,

<http:// wnw.consilium.europa.eu/ueDocs/cms_Data/docs/pressData/en/ec/kolnen.htm>

, (access date: 4 March 2010).

19 "EU Helsinki Summit Decisions", Annex 1 to Annex IV, 
establishment of a Rapid Reaction Force up to corps level 50-60 thousand persons ( 15 brigades) by the year 2003, backing up these forces as necessary, and deploying it within 60 days, and being able to sustain such a deployment for at least one year. ${ }^{20}$ Furthermore, it was stated openly that National Forces assigned to NATO by the European Allies will also be used for the EU-led operations. This way, the EU has come closer to its goal of automatically utilizing NATO assets and capabilities and is weakening the veto power of non-EU European Allies in NATO. On the other hand, in order to satisfy the non-EU European Allies, it also put forth a structure composed of non-EU European Allies and EU candidate countries in order for bilateral talks in crises management and exchange of information. But the forum, without decision-making capacity, is far away satisfying the non-EU European Allies. Because, The EU especially emphasized that the Allies must respect the EU's right to make decisions and its organizational structure in particular. In conclusion, the EU's desire to utilize NATO's assets and capabilities without any additional expenses and restraints was put forward once again.

Decisions on transferring the ESDI responsibilities to the EU, and the WEU as an organization having completed its purpose by the end of 2000, were agreed on in the EU Cologne Summit, but in the consequent Helsinki and Feira Summits no steps were taken regarding the closing of the WEU. In my opinion, this was a an attempt to eliminate the persistent attitudes of the non-EU European Allies like Turkey to guarantee their gains within the WEU and to overcome the sentiments of neutral countries of the EU such as Sweden and Finland in transferring the Treaty of Brussels, which entails the WEU along with collective defense, to the EU. As a result of the consultations, EU countries have decided to transfer the necessary aspects of the

<http:// www.consilium.europa.eu/ueDocs/cms_Data/docs/pressData/en/ec/ACFA4C. htm >, (access date: 27 March 2010).

${ }^{20}$ EU Helsinki Summit Decisions, p. 1, <http:// mwn.consilium.europa.eu/ueDocs/cms_Data/docs/pressData/en/ec/ACFA4C. htm >, (access date: 27 March 2010). 
The European Security Architecture and Turkey

ESDI instead of closing the WEU as a whole, to preserve the ratified 1948 Brussels Treaty and for collective defense, which might be necessary in the future.

\section{II) EU's Efforts to Create Armed Forces and a Planning Headquarters: EU-NATO Relations}

\section{EU Military Power, Headline Goal (HG)}

With the Cologne Summit of June 1999, the EU has initiated a process aimed at the creation of assets and capabilities, in order to conduct crisis management tasks. In the 1999 Helsinki Summit, it was agreed that, member states must be able, by 2003, to deploy within 60 days and sustain for at least 1 year military forces of up to 50,000-60,000 strong capable of the full range of Petersberg tasks for EU-led operations. This force, also called as the Rapid Reaction Force, was not entirely implemented as a result of the reluctant attitude of some EU countries.

In the Defense Ministers Meeting held in Brussels on 2021 November 2000 and the EU Summit held in Nice on 7-11 December 2000, it was expressed that only EU member countries may contribute to the Headline Goal, while contributions of non-EU Allies will be considered as "additional". What does "additional" mean here? The interpretation of this, Turkey may provide some forces for the ESDI, but the EU may consider it unnecessary, and may not include those Turkish forces its operational plans. This decision has put non-EU European Allies, such as Turkey, in a difficult position. Another surprising decision for the Non-EU Allies (Turkey, Norway, Iceland) to not take part in EU-led operations using NATO assets and capabilities, is contradictory to the essential principles which were discussed until now and agreed upon. 


\section{Battle Groups (BG)}

The Battle Groups is a French and British initiative agreed upon in the Franco-British Summit taking place in Le Touquet on 4 February 2004, but was concluded more openly on 24 November 2003 in London. ${ }^{21}$ It was foreseen that BG's are to reach their final operation capability (FOC) in January $2007 .{ }^{22}$ It is useful to examine the details of what these Battle Groups entail.

This force will be battalion level and consist of well trained and equipped personnel. Each battalion is to consist of 1500 strong. It was provided that this force should be able to be ready for operation within 15 days, serve in the operational theatre for 30 days without any support, and deploy for 120 days. It was also foreseen that the land force to be formed would be a brigade consisting of 13 battalions.

\section{Humanitarian Aid and Crisis Management Operations Conducted by the EU}

Following the operations conducted by the WEU, starting with the Police Mission in Bosnia and Herzegovina and continuing with Althea, the operations of the EU have spanned from Kosovo to Palestine, Georgia, Iraq, Indonesia and Somali. It would not be wrong to say that with these operations, a final operation capability relating to the creation of a force, logistic, finance and decision

21 "The Battlegroups", 12 September 2008, Brussels, EU Parliament Directorate-General for External Policies of the Union, <bttp:/ / wnw.europarl.europa.eu/meetdocs/2004_2009/documents/dv/ studybattlegrouppe381401_/ studybattlegrouppe381401_en.pdf>, (access date: 24 March 2010).

22 <http://www.consilium.europea.eu/showPage.ASP?lang=en>, (access date: 12 March 2010). 
The European Security Architecture and Turkey

mechanism was achieved. The conduction of the ISAF-5 operation in Afghanistan by EUROCORP, earmarked to the EU, has made its most significant contribution to CFSP as far as peace-keeping operation is concerned.

\section{EU Planning Assets and Capabilities and the Related Institutions}

Helsinki 1999 EU Summit's decisions on ESDI are as follows. NATO is first to intervene in a crisis; the ESDP operation is to be conducted within the framework of the Berlin ( + ) by utilizing NATO's assets and capabilities; ESDP avoids unnecessary duplications. ${ }^{23}$ However, the EU has not fully implemented these decisions. Many foundations, including the establishment of the European Security and Defense College (ESDC) ${ }^{24}$ similar to the NATO Defense College, were re-established under the EU. Those duplications were named "necessary duplications", including the Political and Security Committee (PSC), the EU Military Committee and the EU Military Staff (EUMS). The EU Military Headquarters does not have fully organized Operation Center, but a Situation Center. Taking into account the requirement French President Chirac has stated that, "We must now think of giving a permanent dimension to our collective command and operation instrument through the Ops Center set up in the EU". ${ }^{25}$ In fact, this initiative of France arises from their efforts to physically keep CFSP outside of NATO. As known, in accordance with the agreed Berlin (+) arrangements, the EU has assured access to NATO's planning assets and capabilities able to contribute to military planning for the EU-led operations. SHAPE, NATO Headquarters is also used by the EU. Within this scope, the EU Military Committee could assign tasks to SHAPE, which will be

\footnotetext{
23 "Helsinki Summit Decisions", Annex-IV, EU Council.

${ }^{24}$ European Security and Defense College,

<http://europa.eu/scadplus/leg/en/lvb/r00003.htm>, (access date: 07 March 2010).

25 Jacques Chirac, "France’s Vision for NATO", Christian Monitor, 28 November 2006.
} 
completed and delivered back to the EU, under the responsibility of DSACEUR. SHAPE is no longer only headquarters of NATO, but is also an EU headquarters. The waving EU flag next to the NATO flag on the roof of the HQs is the most important evidence.

\section{The Current Situation in NATO-EU Relations}

In the NATO Heads of State and Government Summit in Riga on 28-29 December 2006, French President Chirac has stated that "having numerous global threats, NATO's security power cannot be downgraded", but NATO has to combine its efforts with the EU and that the EU, within the context of its historical and cultural structure, is in a more suitable position to defend Europe. ${ }^{26}$

However, the EU still regards its gains obtained from NATO as not enough and accuses NATO members, especially Turkey, of disrupting EDSP. What is this accusation? Greek Cypriot government is not able to participate in ESDP activities within the EU despite being a member of it. Upon Malta becoming a PfP country in the Bucharest Summit ${ }^{27}$ and signing a security agreement with NATO, only Greek Cypriot government remains as an EU member outside of ESDP. What is the issue? The problem is not actually Turkey, but the agreement signed between NATO and the EU. As far as NATO-EU cooperation is concerned the NATO-EU Security agreement reads that an EU country involved in the EU's defense dimension it must conclude a security agreement with NATO. The easiest way to implement this agreement is to be a member of the NATO PfP program. ${ }^{28}$

${ }^{26}$ Idem.

27 "NATO Bucharest Summit Declaration", Art. 32,

<http:/ / www.nato.int/docu/pr/2008/p08-049e.html>, (access date: 07 March 2009). 28 See: NATO-EU Security Agreement, para. 4(d) and para 5(a), read that "classified information may be disclosed or released to members of NATO and other EU states which have subscribed to the PfP framework and, in this context, have a valid security agreement with NATO". 
The European Security Architecture and Turkey

Greek Cypriot government, unfortunately, refrains from applying to this program. Greek Cypriot officials' excuse in backstage is that Turkey never accepts the application. The problem here is that this doesn't reflect the reality. It seems that the Greek Cypriots do not want the Cyprus issue to become a discussion topic in NATO at a time when peace processes are going on.

\section{III) Turkey's Position and Achievements in the Development of European Security and Defense Identity}

Following the ESDP being transferred to the EU, whether Turkey would have a role in the decision mechanisms of EU operations, in particular, whether she would participate in the EUled operations which utilize NATO's assets, and whether she could safeguard the acquies gained in the WEU has emerged as one of the most important topics being discussed in Turkey's relations both with NATO and the EU. Turkish Media has discussed this topic several days, criticizing the logic that sending troops for an EU operation without taking part in its decision making process.

At this point it is necessary to explain the EU decision mechanism regarding an EU operation. The EU Political Security Committee (PSC), established under the EU Council, performs strategic control and political guidance of the operations, makes all kinds of decisions, and the Operations Commander will take action depending on the PSC. However, these decisions must be approved by the EU Council. Non-EU Allies or other volunteer countries may provide military contribution for the EU-led operations. Those countries' representatives seat in a "Committee of Contributors". And the EU has stated that this Committee will participate in the daily management and conducting of the operations with equal rights. Moreover, it was also expressed that the decision to end the operations will not be taken by the EU Council without consulting the participants. It is clear that the Committee of Contributors with equal rights have no function in 
the strategic and political control of the operation. This means that non-EU European allies which contribute to operations by sending troops will not take part in the decision mechanisms. They only receive Operations Commander briefings from time to time.

Turkey has proposed that the Committee of Contributors should be placed somewhere between the Operations Commander and the PSC and involved in the planning and conducting phases of the operation, still agreeing that the final decisions will be taken by the PSC. However, it was not possible to convince the EU countries.

\section{Turkey's Gains in the WEU and its Participation Policies in the ESDP}

What were Turkey's gains from the WEU that she has put forth and significantly emphasized? Through an effective and balanced policy, Turkey, as an associated member of the WEU, has obtained numerous significant gains within the ESDI and WEU, including decision-making mechanisms, which are close to full membership rights. First of all, while signing the Associate Membership Agreement, it was guaranteed that "they will take part on the same basis as full members in WEU military operations to which they commit forces". ${ }^{29}$ Later on, these statements were reflected in the decision of the WEU Ostend Council of Ministers Summit on 19 November 1996 and the participation of non-EU European Allies, such as Turkey, in WEU operation planning and preparation using NATO assets and capabilities, was accepted. ${ }^{30}$ Also, the decision of the WEU Council of Ministers to adopt the declaration attached to the Treaty of Amsterdam on 22 July 1997,

\footnotetext{
29 See: Document on Associate Membership of WEU of the Republic of Iceland, the Kingdom of Norway and the Republic of Turkey, Rome, 20 November 1992: "they will take part on the same basis as full members in WEU military operations to which they commit forces".

30 See: WEU Ostend Ministerial Declaration, 19 November 1996, para. 18: "The participation of European Allies in WEU operations using NATO assets and capabilities, as well as in the planning and preparation of such operations".
} 
The European Security Architecture and Turkey

guaranteed that Associate Members are to take part on the same basis as full members in WEU operations to which they contribute, as well as in relevant exercises. ${ }^{31}$ And this was acknowledged in the WEU Council of Ministers Erfurt meeting. ${ }^{32}$ These are the most important gains achieved by non-EU European allies such as Turkey. However, those gains in the WEU and ESDI have created obstacles for Turkey as far as its participation in the EU's security architecture.

\section{NATO Washington Summit (23-24 April 1999)}

While Turkey was going to NATO's Washington Summit with these gains in hand, she was planning to further develop the rights within the defense dimension of the EU. Before the Summit, EU countries, with the UK at the forefront, were convinced in their concerns towards the EU's independent and autonomous defense dimension. But the US government had some concerns in the Summit. In Washington, NATO's New Strategic Concept was adopted and important decisions were made, particularly in crisis management and in the NATO-ESDI context. Turkey has worked towards maintaining its gains earned within the context of WEU-NATO and with the understanding of further developing these in the EU-NATO context. Despite not being entirely successful in its strategy, Turkey has been able to include the statements related to maintaining its gains and keeping Turkey at the negotiating table, in both NATO's Strategic Concept

\footnotetext{
31 See: Declaration adopted by the WEU Council of Ministers on 22 July 1997 and attached to the Final Act of the Intergovernmental Conference concluded with the signature of the Amsterdam Treaty, on 2 October 199, p. 8: "WEU recalls that Associate Members take part on the same basis as full members in operations to which they contribute, as well as in relevant exercises and planning".

32 See: WEU Council of Ministers Erfurt Declaration, 18 November 1997, para. 29: "Ministers welcomed the improved arrangements allowing Associate Members and Observer States to participate fully in accordance with their status in all Petersburg operations undertaken by WEU".
} 
and Summit Declaration. ${ }^{33}$ Article 9 of the Summit Declaration states that the EU has the capacity for autonomous action where NATO as a whole is not engaged, NATO-EU practices should be built on the mechanisms existing between NATO and the WEU, and that the utmost importance is given to ensuring the fullest possible involvement of non-EU European Allies in EU-led crisis response operations, building on existing consultation arrangements within the WEU. ${ }^{34}$ On the basis of the principles laid down in article 9, article 10 of the declaration indicates assured EU access to NATO planning capabilities; the presumption of availability to the EU of pre-identified NATO capabilities and common assets for use in EU-led operations; identification of options for EU-led operations to further develop the role of DSACEUR in order for him to assume fully and effectively his European responsibilities; and the further adaptation of NATO's defense planning system to incorporate more comprehensively the availability of forces for EU-led operations and tasks the Council in Permanent Session to address these measures. ${ }^{35}$

In article 17 within the scope of ESDI of the renewed NATO Strategic Concept in the Summit, ${ }^{36}$ it is stated that "the EU has taken important decisions and given a further impetus to its efforts to strengthen its security and defense dimension. This process will have implications for the entire Alliance and all European Allies (Turkey, Norway, Iceland and the new three members) should be involved in it, building on arrangements developed by NATO and the WEU'. In short, WEU acquired rights were taken as the basis for the practices to be exercised in the future. Moreover, article 30 existing under the title of ESDI of the Strategic Concept ${ }^{37}$ states that "on the basis of decisions taken by the Alliance, in Berlin in 1996 and subsequently, the ESDI will

33 The Reader's Guide to the NATO Summit in Washington, 23-25 April 1999, Brussels, Office of Information and Press of NATO, 1999.

34 Ibid., Art. 9, p. 16.

35 Ibid., Art. 10, pp. 16-17.

${ }^{36}$ Ibid., pp. 49-50.

${ }^{37}$ Ibid., p. 52. 
continue to be developed within NATO. This will enable all the European Allies to make a more coherent and effective contribution to the missions and activities of the Alliance. It assists the European allies to act by themselves as on a case-by-case basis and by consensus to make their assets and capabilities available for operations in which the Alliance is not engaged military and taking into account the full participation of all European Allies".

Article 9/b. of the Washington Summit Declaration is highly important for Turkey. It conveys that NATO-EU cooperation will develop by building it on the mechanisms existing between NATO and the WEU. ${ }^{38}$ This article provides that the gains of European allies, like Turkey, will be protected within the scope of NATOEU cooperation and will even be developed further. On the other hand, article 9.d. ${ }^{39}$ puts forth that the utmost importance is given to ensuring the fullest possible involvement of non-EU European Allies in NATO supported EU operations based on the existing mechanisms between NATO and the WEU. These decisions have blocked the EU from fully utilizing the NATO assets and capabilities in an operation in which NATO does not participate as a whole and have guaranteed Turkey's approval for each decision. Moreover, the articles have given authorization for the transferring of the existing gains in the WEU to the new defense dimension of the EU. Having these decisions, Turkey struggled for the implementation, but with could not convince the EU countries. The subsequent improvement with the Ankara Document which is a compromise proposed by Turkey will be examined below.

Although the principle agreed upon in Washington that the "EU will make decisions in situations where NATO as a whole is not engaged in the military operations" can be perceived as "NATO first", it does not guarantee that NATO will always be at the forefront for future crises, because any objection from a NATO and EU member country will be enough to block NATO's intervention. On the other hand, NATO military assets and

${ }^{38}$ Ibid., p. 16.

${ }^{39}$ Ibid., pp. 16-17. 
capabilities, apart from common ones like Airborne Warning and Control Systems (AWACS), which could be given to the EU-led operations with Turkey's approval, are regarded as national military assets of EU countries. Although this is seen as a protective mechanism granted to Turkey, it is not a matter to which Turkey could easily say "no" in a real crisis situation in which the EU is acting to stop all the bloodshed.

Furthermore, presuming that a crisis will not take place for a long time in the future, non-EU European allies like Turkey, will remain outside the ESDI during peace time. Therefore, if the EU had automatic and guaranteed access to NATO planning capabilities, it would be possible that "an EU-led operation utilizing NATO assets and capabilities" would no longer be the case in the future.

While the USA Secretary of State Albright was expressing the cases for NATO-EU cooperation, she has put forward the principles known as 3D's. 3D's stands for "no duplication, no discrimination, no de-coupling". However, the EU has responded ${ }^{40}$ with different terminologies such as "autonomous action, separable but not separate forces ${ }^{41}$ and unnecessary duplications". ${ }^{42}$

The US Government has claimed that the decisions taken prior to Helsinki contradict, in particular the EU Cologne decisions created concerns in the USA. ${ }^{43}$ However, the EU

\footnotetext{
${ }^{40}$ Michael J. Brenner, Europe's New Security Vocation, Washington DC, Institute for National Strategic Studies National Defense University, 2002, p. 10.

${ }^{41}$ The Reader's..., Art. 9e, p. 16.

${ }^{42}$ EU Helsinki Summit Declaration, Art. 27, <http:// wnw.consilium.europa.eu/ueDocs/cms_Data/ docs pressData/en/ec/ACFA4C.htm>, (access date: 27 March 2010).

43 See: ABD Senator Douglas Bereuter's statement delivered on 22 February 2000 in the European Parliament on the matter regarding ESDP: "Tracing back the steps that led to Helsinki, he expressed the prevailing American feeling that by locating ESDI clearly in the EU, Cologne had been a surprise for American decision-makers, as this seemed to depart from the earlier NATO consensus
} 
The European Security Architecture and Turkey

countries have replied that those institutional duplications and repetitions are "necessary duplications".

Positions expressed within the Washington decisions and called as Berlin $(+)$, have locked NATO's decision mechanism between 1999-2002, as a result of Turkey's persistent efforts to safeguard its rights within the WEU. No longer being able to resist the pressures on this matter, Turkey has presented the draft "Ankara Document". With the agreement on this document, the participation of non-EU European allies in EU-led operations were identified and "ESDP: Implementation of the Nice Provisions on the Involvement of the Non-EU European Allies" paper was attached to the EU Brussels Summit decisions (25 October 2002). ${ }^{44}$ The paragraph 3 of the subject paper reads that "Additional $15+6$ meetings ${ }^{45}$ will be arranged as required. In particular, consultations will, as appropriate, involve additional meetings in the format of EU +6 in advance of PSC and EUMC meetings where decisions may be taken on matters affecting the security interests of the Non-EU European Allies. The objective of these consultations will be for the $\mathrm{EU}$ and the non-EU European Allies to exchange views, and to discuss any concerns and interests raised by these Allies, so as to enable the EU to take them into consideration."

However, in practice the EU has not even been able to exercise the rights provided in its own document. Even though the EU consider its potential area of interest and operations covers Turkey's geographical vicinity and naturally its security interests,

that ESDI should be firmly anchored in the Alliance. Be that as it may, the US Administration and Congress had expressed concern that ESDI/P could lead to the fatal three Ds: 'Decoupling', 'Duplication' and 'Discrimination' within NATO".

44 "ESDP: Implementation of The Nice Provisions on The Involvement of the Non-EU European Allies”, 25 October 2002,

< bttp:// wnw.consilium.europa.eu/ueDocs/cms_Data/docs/pressData/en/ec/ 72968.pdf. >, (access date: 30 April 2010).

${ }^{45}$ Six Non-EU European Allies are Turkey, Iceland, Norway, Hungary, Poland and Czech Republic. 
Turkey was not granted a place in the EU's Common Foreign and Security Policy. Despite Turkey was compromising attitude on all matters within the context of NATO-EU cooperation on ESDP. Turkey was participating in EU-led operations and sending troops without its institutional position was clarified. Turkey's initiatives were not only being reflected on its institutional relations and cooperation with the EU, but also on the Common Foreign and Security Policy and on security mechanisms. ${ }^{46}$ Since Turkey's demands were not met, Turkey has suspended its military contributions guaranteed to the EU Headline Goal at the end of $2008 .^{47}$

\section{Europe's Security Concerns in the Post-Cold War Period}

Turkey contributed to Europe's defense during the Cold War and helped the stability in the south flank. Why is it being ignored now? Regarding Turkey's membership, from time to time, some EU countries are referring the geography disputing Turkey's location, its troubled neighborhood and its growing population, and that EU is enlargement fatigue. Although these arguments contain some truth in it, it is at no point to cause fear. Even though Turkey's neighbors are accepted as being troublesome, Turkey's main orientation is Europe. Turkey can play a key role between the EU and these countries. In for Turkey's high population growth rate, the EU has already taken its precautions. And the argument that Turkey can change the existing balance inside Europe is not plausible since the EU increased the number of its member states from 16 to 27 within a very short time. It

\footnotetext{
46 Atilla Eralp, “Avrupa Birliği'nde Lizbon Antlaşması çerçevesinde yapılmaya çabalanan kurumsallaşma sürecini, aynı zamanda da Avrupa Birliği Başkanlığına Herman van Rompuy'un seçilmesini yorumladı, 2009",

< bttp:// wnw.foreignpolicy.org.tr/turkish/dosyalar/aeralp_111209.html>, (access date: 30 April 2010).

47 "MSB Speech of Vecdi Gönül”, Turkey-NATO Assembly, Antalya Security Conference, (access date: 30-31 January 2009).
} 
should not be a huge problem to absorb another country as 28 th member.

From time to time, French authorities declare that Turkey is not geographically part of Europe. What are the borders of Europe? Where do they start, where do they end? One of the theses put forward on this topic is that the borders of Europe were identified with the Roman Empire. Therefore, regions including Northern Caucasus are within the borders of Europe. This thesis was also reinforced on 4-9 September 1962, by French President Charles de Gaulle's description of "Europe from the Atlantic to the Urals", during his visit to West Germany. ${ }^{48}$ On the other hand, Thrace, being a very small region of Turkey but being larger than some European territories, is located in Europe which the Europeans have accepted. If an island or a tiny rock provides amazing rights to the country which owns it, then it is not rational to overlook Thrace and say that Turkey is not on the map of Europe. Apart from all these, if Turkey is not geographically part of the European Continent, it would then be difficult to count Cyprus as part of Europe. ${ }^{49}$

On the other hand, within the context of the developments in the ESDP, German Prime Minister Angela Merkel and French President Sarkozy have stated in the 45th Security Conference held in Munich on 7 February 2009 that Russian Federation (RF) should also be included in European Security and that it would not be a threat to NATO and Europe. This approach is highly similar to "European Security Treaty" 50 statement repeated by RF President Medvedev in Germany and subsequently in France on 5 June 2008. Slightly changing Charles de Gaulle's statement, Sarkozy has expressed the description of "Europe: from

48 Yuri Dubinin, "Europe from the Atlantic to the Urals", Russia in Global Affairs, No: 4 (October - December 2007),

<http:/ / eng.globalaffairs.ru/printver/ 1156.html>, (access date: 08 March 2010).

49 Onur Öymen, Dr., CHP Vice Chairman, TBMM speech, 26 May 2007.

50 "Russian President Calls for Binding European Security Treaty", <http://en.rian.ru/russia/20080605/ 109342586.html>, (access date: 12 March 2010). 
Vancouver to Vladivostok" in this meeting. ${ }^{51}$ In the speech delivered in the French National Assembly on 12 February 2009, NATO's former General Secretary Jaap de Hoop Scheffer has stated that "The French conditions for returning to NATO Military Command, to develop NATO-RF relations is important". ${ }^{52}$ In NATO's 60th anniversary Summit on 3-4 April 2009 in Strasbourg/Kehl, important decisions were made in relation to France returning and improving the NATO-RF relations. In respect to the positive approach resulting from the NATO Summit, the EU will increase its efforts for a strategic partnership with the RF in the upcoming period. In NATO's Bucharest Summit of April 2008, the NATO Council's Brussels meeting of December 2008, and the Strasbourg/Kehl Summit, the first signs were given by Germany and France opposing Ukraine and Georgia joining the Membership Action Plan (MAP), which the US in particular desired the most, by taking EU-Russia relations into account.

\section{Conclusion}

Europe is a continent on which the bloodiest wars have taken place and which has witnessed the two World Wars and was the main theater of the Cold War. However, in the new world order emerging after 1945, the EEC/EU has truly marked a great irrevocable success in the integration of Europe. In 1990, with the Cold War coming to an end, Europe has entered into a period of peace which it had never had throughout its history. European states, solving the problems between them through compromise, have shown efforts to develop the defense dimension within their own area of interest. The EU has improved the ESDP to a

51 "Focus on European Security", 45 $5^{\text {th }}$ Munich Security Conference, February 2009, <http:/ / www.securityconference.de/konferenzen/2009/europaeische_sicherheit.php?sprache = en¿广>, (access date: 08 March 2010).

52 "General Secretary Jaap de Hoop Scheffer's Speech in the French National Assembly", 12 February 2009,

<http://wnw.nato.int/cps/en/natolive/opinions_51356.htm>, (access date: 15 May 2010). 
The European Security Architecture and Turkey

reasonable level separate from NATO and the USA and with an independent defense structure. The EU has almost completed the organizational structure of the ESDP. In particular, it has achieved sufficient experience in fulfilling the Petersberg tasks in relation to crisis management. The EU plans to keep NATO confined in article 5 of collective defense, to block NATO's out-of-area activities to a certain measure in the NATO Council, and prefers out-of-area crisis management operations to be conducted by itself. 21 out of the 28 NATO members are also EU members and they have the power to prevent any decisions to be taken in NATO that would not be beneficial to the EU. Moreover, the EU has obtained assured access to NATO's SHAPE Military Headquarters; thus, no longer having any significant requests from NATO. Therefore, despite the terminology of "an EU-led operation utilizing NATO assets and capabilities" being highly discussed until today, it might no longer come into question in the future. This matter will weaken the role of non-EU European Allies, such as Turkey, in the ESDP. In that period, the Turkish Prime Minister Bülent Ecevit had a concern that, the EU may have an increasing effect on regional crises that could arise in Turkey's neighboring areas, instead of NATO. However this concern has been dispelled by the EU and Turkey has shown a compromise for future NATO-EU relations. ${ }^{53}$

With the status of associated member in the WEU, Turkey had much more privileged rights than non-NATO EU countries (Sweden, Finland, Austria, and Ireland). With their gains in the ESDI close to those of full members, Turkey plans to further develop them with the EU candidate status given in 1999. This was seen as Turkey's most natural right, because when she was not

\footnotetext{
53 See: "ESDP: Implementation of The Nice Provisions on The Involvement of the Non-EU European Allies", 25 October 2002, para. 2: "For the Member States concerned, this means that the actions and decisions they undertake within the framework of EU military crisis management will respect at all times all their Treaty obligations as NATO allies. This also means that under no circumstances, nor in any crisis, will ESDP be used against an Ally",

< http:// wnw.consilium.europa.eu/ueDocs/cms_Data/docs/pressData/en/ec/ 72968.pdf. >, (access date: 30 Apr 2010).
} 
even a candidate member, she had important roles within NATO for Europe's defense and obtained great achievements in the WEU. After acquiring an EU candidate status in 1999, Turkey aimed to further improve these gains. However, its expectations were not fulfilled and it even lost its gains. When the promises made were forgotten and obstacles kept coming up each time, Turkey became highly disturbed with these developments and also became weary of the struggles they displayed; thus, with a unilateral decision taken in 2007, Turkey withdrew, its military contribution for the EU's Headline Goal and gave indications that she would break away from the ESDP. Turkey displayed its disappointment by issuing a letter that called for the EU countries to keep their promises and remain loyal to their signatures ${ }^{54}$ in December 2008. Taking into account, the NATO Bucharest and Kehl/Strasbourg summits, and 2009 Munich Security Conference outcomes, we can reach a conclusion that European Security without RF is almost unthinkable. EU's trade relations with and especially energy needs from RF and also EU's policies in Caucasus need to compromise with RF. Notwithstanding of the USA strong desire, EU countries- led by Germany and France have refused the Ukraine and Georgia membership to NATO, considering RF's callings. EU and RF in the near future may initiate a discussion and come to a conclusion on a European Security Treaty, using The Organization for Security and Cooperation in Europe (OSCE) platforms.

The EU and the US are dependent on foreign countries for natural resources. Taking into consideration the need for natural resources in the upcoming 50 years, the US is attempting to guarantee its strategic needs by using its armed forces today. Although the EU, being in a similar situation, has developed its defense units, it still remains behind the US. Due to the weakness of its military power remaining behind the US, the EU presents a more democratic and cooperative stance in international crises and with its economic power and ties, plans to achieve similar strategic

54 "MSB Speech of Vecdi Gönül”, Turkey-NATO Assembly, Antalya Security Conference, 30-31 January 2009. 
The European Security Architecture and Turkey

goals with the US. The EU, by increasing its relations with the RF in areas of trade, economics, defense and cooperation, and including the RF into European security, will become a leading world power in the forthcoming period.

EU countries, which emphasize NATO's role in the collective defense of Europe, also do not refrain from expressing that collective defense had been a strategy of the past and that the $\mathrm{RF}$ would never be a threat for Europe. It is clearly seen that the hidden aim behind these statements "NATO to remain standing against collective threats to Europe if any, but the EU assumes responsibility for all crisis management operations". In this situation, it is possible for NATO to become evolved into an organization and an arsenal for EU-led operations. Taking into account the actions carried out in recent years by NATO, a significant amount of the efforts were delivered for peace support operations, activities of PfP, and Combined Joint Task Force (CJTF) practices. If these activities are taken on by the EU and relations with the RF improve, NATO could become a passive institution only responsible for the collective defense of member states.

Up until now, the EU has achieved important developments and the most vital measure remaining right now is the Common Foreign and Security Policy. In the following years, the current situation will continue. This course will have its ups and downs and is closely related to whether US existence in Europe will continue or not. However, these developments will also have a direct effect on US-Russian relations and the new structuring of Russia. Being aware that without progressing in this direction, it cannot be effective in world politics, the EU will continue to increase its outlined practices. The new NATO Strategic Concept, most probably, to be tabled in 2011 will provide important inputs as far as NATO's world strategy, its global duties, NATO-EU relations and cooperation with RF are concerned. NATO will be primarily responsible for only collective defense, if it couldn't succeed in updating its responsibilities and duties. And ESDP will 
shoulder crisis management responsibilities with some remarkable changes in NATO.

Needless to say, US-EU relations and the EU strategic organization not being entirely and soundly structured and the future of strategic-economic relations between the US and the EU will be vital for these practices. The USA might get closer cooperation with Russia while having close economic ties with the EU within the global scene. 